\title{
CONTROL OF THE LAUREL THRIPS, GYNAIKOTHRIPS FICORUM MARCHAL
}

\section{George N. Wolcott ${ }^{1}$ \\ INTRODUCTION}

The density of evergreen foliage of Ficus nitida Thumb., "laurel de la India," as it is called in Puerto Rico, or the "India laurel fig" of Florida nurserymen, with its small, waxy, shining leaves, oval but pointed at both ends, has caused its selection for shading the plaza or promenade of many a tropical city. The most serious objection to laurel is its susceptibility to mass infestations of the tropicosmopolitan thrips originally described (1) ${ }^{2}$ by P. Marchal as Phloethrips ficorum from Algeria, but now present by accidental introduction in such widely separated localities as Java, Gusm, the Canary Islands, southern Florida, Cuba, Hispaniola, and Puerto Rico.

The feeding of the adult thrips on the tender light-green leaf is initially marked by sunken reddish spots along the midrib, but the tight curling of the leaf is caused by the development of colonies in the immature stages. As the nymphs mature, the tightly curled leaf becomes hard and tough, then gradually yellower and browner, and adheres less tightly to the twig, so that thousands may drop at the first heavy rain after an extended period of dry weather, covering sidewalks and pavements with unsightly windrows of debris. The thrips ordinarily do not attack other vegetation, and indeed most species of Ficus are largely or entirely immune to infestation, but when they become abundant on their specific and preferred host, they tend to cause defoliation of all the new leaves on the outside of the tree. (Fig. 1.)

The thrips do not intentionally bite people, but they are a terrific nuisance to people resting or promenading underneath infested laurels, getting in the eyes, or entangled in the hair, and ticking the skin as they attempt to escape. Students of the University of Puerto Rico, attempting to study on the benches or in cars parked under the laurel trees that have been so universally planted for the adornment of the campus, find these little hard black insects dropping from the trees very annoying.

\section{CONTROL}

The availability of a single, moderate-sized laurel de la India tree, comparatively isolated on the grounds of the Agricultural Experiment Station at Río Piedras, has made possible experiments in the control of this thrips. Preliminary tests with 1-percent and 0.5-percent Aldrin on part of another

\footnotetext{
${ }^{1}$ Entomologist and Head of Department, Agricultural Experiment Station, University of Puerto Rico, Río Piedras, P. R.

${ }^{2}$ Numbers in parentheses refer to Literature Cited, p. 240.
} 
tree indicated that all thrips were promptly killed by spraying, and the experiment proper was commenced, using Aldrin at 0.25 -percent concentration on March 18, 1950. This was also effective, but few thrips were

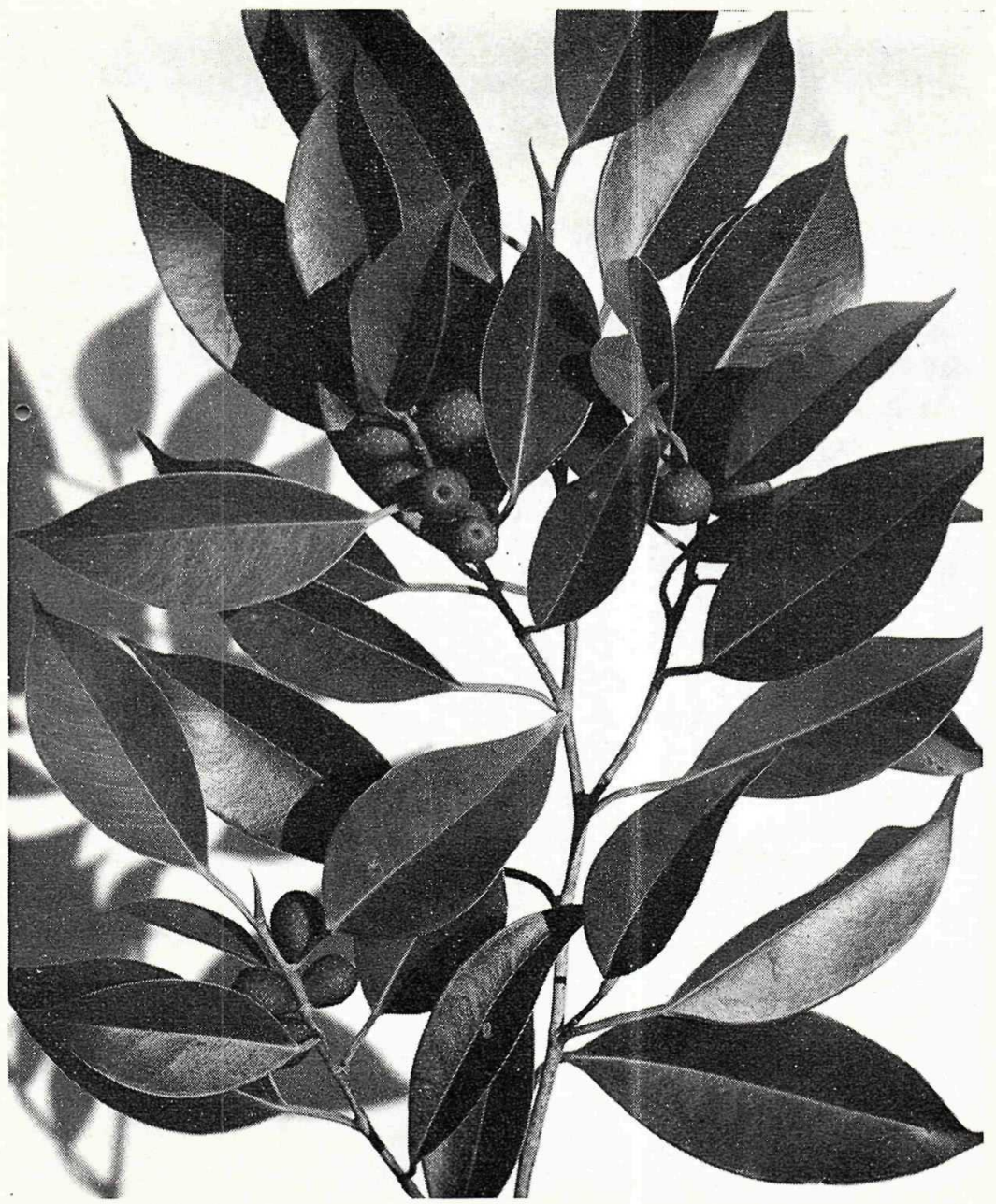

FIG. 1.-Twig of Ficus nitida, showing thrips-distorted leaves and partial defoliation caused by thrips infestation. (Original)

killed by a subsequent spraying at a dilution of 0.125 -percent, and spraying had to be promptly repeated when 0.25 -percent was used. Despite the tight curling of the leaves all thrips succumbed to the spray, so that within a few hours after treatment, only dead ones could be found. The comparative isolation of the tree did not prevent reinfestation from unsprayed trees 
a few hundred yards away. Residual effect did not protect fresh foliage, and the tree had to be sprayed at intervals of $11 / 2$ to 2 months, as soon as adults were noted in any curled leaves. Applications of Dieldrin were alternated with those of Aldrin, with no appreciable difference in the results. (Fig. 2.)

When inhabited by colonies of live thrips: Eggs, nymphs, and adults, the curled leaves rarely shelter.other animals except those predaceous upon them: Anthocorid bugs, Macrotracheliella laevis Champion and Cardiastethus rugicollis Champion reported by Dr. H. L. Dozier (2), besides

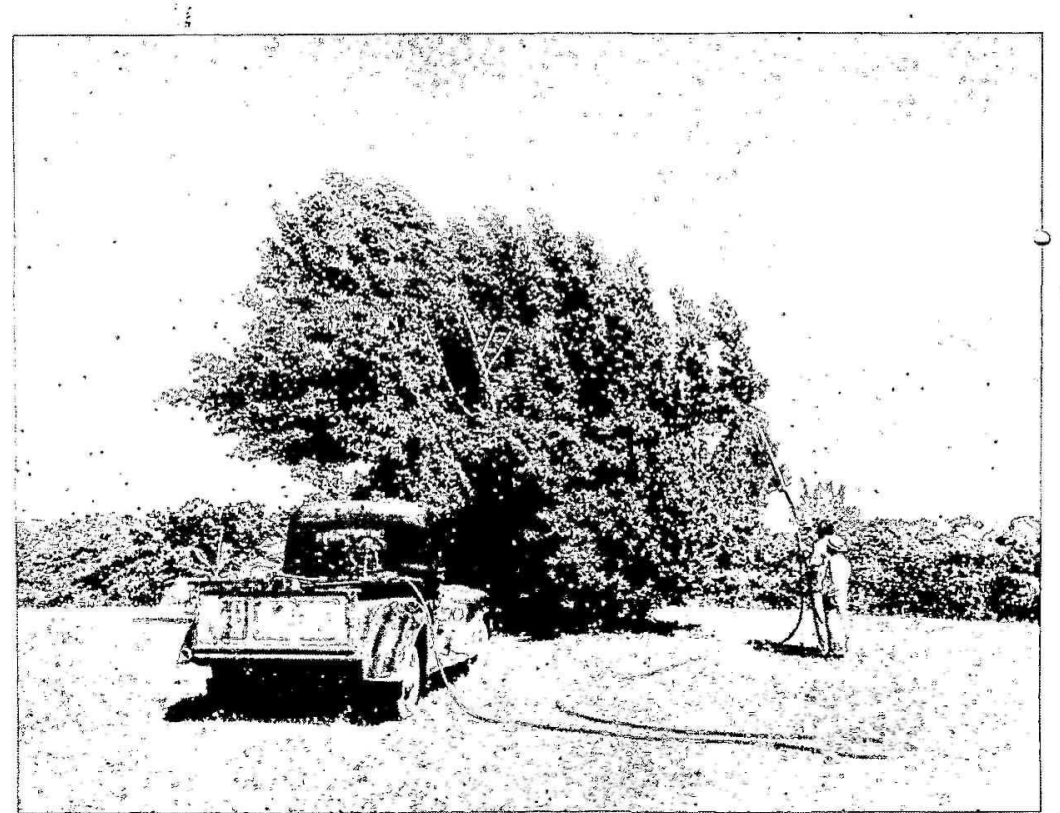

FIG. 2.-Spraying an isolated laurel de la India tree at Río Piedras. (Original.)

orange-colored Dipterous maggots and small ladybeetle larvae. When the thrips have been killed, the curled leaves conceal scale insects such as Ischnaspis longirostris Signoret, the black thread scale, or the "Florida red" scale, Chrysomphalus aonidum Linnaeus (= ficus Ashmead), as well as mites presumably feeding on the dead thrips, and various spiders. Such curled leaves, no longer being injured by the thrips, remain green and as tightly adherent to twigs as normal leaves. They do not fall, and continue as part of the evergreen foliage, despite their initial malformation, but become less conspicuous as fresh growth develops.

Six months after spraying began, many of the originally curled leaves were still present on the tree, despite increasingly heavy scale-insect infestation within. As the experiment continued, it became apparent that to 
eliminate the curled leaves entirely, applications would have to be made as often as a month apart if all distortion of the fresh leaves was to be prevented. Indeed, waiting until a fresh infestation developed before admistering the next spray proved to be the wrong approach if complete protection was to be obtained. Considerable injury developed with great rapidity if spraying were at all delayed, and psychologically the month-anda-half interval proved difficult. Thus the recommendations for control would be spraying with 0.25 -per cent Aldrin at monthly intervals as a permanent routine throughout the year, to be continued for the life of the tree.

\section{REPLACEMENT OF SUSCEPTIBLE WITH THRIPS-IMMUNE SPECIES}

If this continuous round of spraying seems a high price to pay for freedom from thrips injury on laurel trees, it might be suggested that another alternative is replacing the Ficus nitida trees with other species of Ficus that are apparently entirely immune to thrips infestation. Close to the laurel tree used in the experiment was one which has been identified as $F$. benjamina Linnaeus. Its leaves are longer and more pointed at the ends, somewhat more widely spaced apart, but it has a similar dense foliage, and if it seems to have a more drooping natural habit of growth, this should be readily cured by pruning. Its berries are large and abundant, and when ripe, as bright a red as those of holly, although not as shining. Even during the dryest weather over a series of years no thrips infestation has been observed on this tree, and it seems equally free of the scale insects that often attack F. nitida. Entomologically, it is a desert, and in consequence, ever so much more desirable to the general public. (Fig. 3.)

Merely because all observed trees of $F$. benjamina in Puerto Rico are free of thrips infestation, one should not conclude that what appears to be this tree elsewhere is immune to thrips. Nothing could be further from the fact. Those lining the Avenida Independencia of the capitol city of the Dominican Republic are very heavily infested, as well as those in San Pedro de Macorís. D. C. Wolfenbarger (3) reported a severe infestation on a large tree growing in the Subtropical Experiment Station species block at Homestead, Fla., the thrips being identified by J. R. Watson as Gynaikothrips uzeli (Zimmerman), now considered a synonym of G. ficorum (Marchal).

J. Douglas Hood of Cornell University wrote under date of April 11, 1952: "The Ficus thrips seem all to be our old friend ficorum, and I do not understand it. The other workers, all foreign, have found the species of Ficus benjamina constantly to be uzeli." Hood had fresh material from the Dominican Republic and from Homestead, Fla.

H. von Oettingen of Eisleben, Germany, examining material collected from the same tree, supposed to be $F^{\prime}$. benjamina, at Homestead, and from $F$. nitida at the charter airport at Miami, found no difference in color, and 
but minor difference in size of the thrips from the two hosts: "Immerhin sind diese morphologischen Unterschiede vorläufig noch zu gering, um mit Recht von einer besondered Rasse sprechen zu können. Zur Zeit kann man also nur von der Entstehung zweier biologische Rassen sprechen, deren morphologische Unterscheidenur schwach angedeutet sind."

Kellie O'Neill (Miss) of the U. S. National Museum, with a much more extensive series from additional hosts and many countries, found even

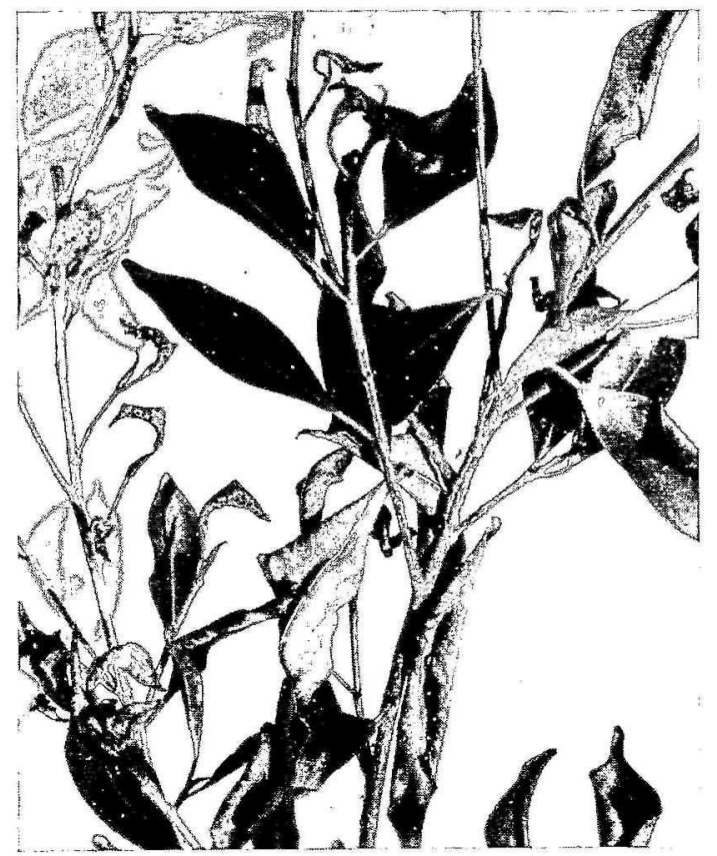

FIG. 3.-Twig of Ficus benjamina, showing fruit and foliage free of thrips injury. (Original.)

greater variations in size that were noted by von Oettingen, but with no consistent pattern based on host selection: "I find that specimens from all localities are smaller from $F$. benjamina than from $F$. nitida, but the range in size is larger than that given by Prof. von Oettingen in every case, so that there is a greater overlap between the ranges. Puerto Rican specimens are generally smaller than Florida specimens, those from $F$. benjamina in Florida being scarcely smaller than those from $F$. nitida in Puerto Rico. Specimens from other hosts either were intermediate in size with a wide range, as in those from $F$. indica, and from Eucalyptus in Cuba, or were larger than specimens from $F$. nitida, with individuals still coming within the upper limits of the figures given by Prof. von Oettingen for those from $F$. benjamina. Hosts of the series of larger specimens were Gliricidia from Puerto 
Rico, 'sapote' from Colombia and citrus from Florida. It is my impression that Gynaikothrips may find $F$. nitida a better host that $F$. benjamina."

\section{DISCUSSION}

From the evidence produced by the studies of three specialists in Thysanoptera it maust be concluded that but a single species of thrips is concerned. If two species actually exist, they certainly cannot be separated by any conspicuous and well-defined morphological character, but only on the basis of host selection.

It seems more probable that the key to the solution of this problem lies in the specific identity of the hosts. This assumes that the thrips-infested trees in the Dominican Republic, which superficially appear to be the same as what has been identified from Puerto Rico as $F$. benjamina, in reality are some other species. The single thrips-infested tree at Homestead supposed to be $F$. benjamina, certainly is not typical if the thrips-free benjamina trees in Puerto Rico and at the Miami Airport are used as a basis for comparison. Nor is the adjacent thrips-free tree at Homestead, identified as $F$. retusa Linnaeus (of which $F$. nitida is by some authorities considered a synonym), typical of the $F$. nitida trees at Miami, or in the Dominican Republic and in Puerto Rico. If these two trees at Homestead are not of another species, this assumption is certainly indicated by the thrips in their avoidance of one and choice of the other.

Insects are more directly concerned with the inherent differences in species of plants than are the systematic botanists, for their living depends ever so much more directly upon the preferential selection of a host most suitable for their nourishment. It may be presumed that the thrips-immune species of Ficus contain in minute amount some essential constituent, toxic or repellent to thrips, which is present in much smaller amount, or not at all, in the leaves of $F$. nitida. We may take advantage of such a clear-cut distinction made by the thrips, and, for the replacement of $F$. nitida, chose cuttings taken from trees the leaves of which are invariably and at all times of year free of thrips infestation.

\section{SUMMARY}

The laurel thrips, Gynaikothrips ficorum (Marchal), may be controlled by spraying at monthly intervals with 0.25 -percent solution of Aldrin or Dieldrin. Or trees of its preferred host, "laurel de la India," Ficus nitida Thumb., may be replaced with quite similar species of Ficus which have been proved to be immune to thrips attack.

\section{RESUMEN}

El trips del laurel, Gynaikothrips ficorum (Marchal), puede controlarse por medio de aspersiones de Aldrín o Dieldrin al 0.25 por ciento, una vez al mes. Otra alternativa sería substituir el laurel de la India, Ficus nitida 
Thumb., árbol hospedero preferido por el trips, por otros similares de la especie Ficus, los cuales han demostrado ser inmunes a los ataques de este tisanóptero.

\section{LITERATURE CITED}

1. Marchal, P., Sur une nouvelle espece de thrips (Thysanopt.) nuisible aux Ficus en Algérie, Bull. de la Soc. Ent. de France, pp. 251-3 1908.

2. Dozier, H. L., Notes on Porto Rican Thysanoptera, J. Dept. Agr. P. R., 10 (3 \& 4) $279-801926$.

3. Wolfenbarger, D. O., Cuban Laurel Thrips Control on Ficus benjamini, Fla. Entomologist, 28 (4) 82-3 1946. 